\title{
WEB UYGUNLUK ANALIZİ: HEPSİBURADA.COM VE N11.COM KARŞILAŞTIRILMASI
}

\author{
Sinem EYICE BAŞEV ${ }^{1}$
}

\begin{abstract}
Özet
Göz izleme, bir web sayfasını görüntüleyen kişinin gözün odaklandığı yeri veya gözün hareketini ölçmeyi içerir. Göz izlemenin amacı, site ziyaretçilerinin, ilgili site üzerinde nereye baktıklarını, ne kadar süre baktıklarını, sayfanın uzunluğuna ne kadar baktıklarını ortaya koymaktır. Araştırmanın modeli durum çalışmasıdır ve araştırma kapsamında internet alışverişi yapılan n11.com ve hepsiburada.com sitelerinin kullanışlılık kıyaslamaları irdelenmiştir. Çalışma kapsamında 25 - 45 yaş aralığında bulunan 19 kişiye bu iki farklı siteye giriş yaparak derin dondurucu almaya çalışılmaları gerekliliği aktarılmış ve uygulama yapılmıştır. İnternet ortamında karşılaşılan sayfadan http://www.n11.com ya da http://www.hepsiburada.com web sayfasını açtıktan sonra önce ana sayfayı incelenmesi ve hemen akabinde de, derin dondurucuların bulunduğu sayfaya ulaşıp Beko Marka Derin Dondurucuları inceledikten sonra Beko 7216 DF kodlu A+ 5 Çekmeceli derin dondurucu sayfasının açılması ve ürünün incelenmesi talep edilmiştir. Daha sonra ürünü sepete ekleyip işlemlere alacakmışsınız gibi devam edilerek, bitirdikten sonra sayfanın kapatılması talep edilmiştir. Çalışmamızda analiz metodu olarak göz izleme yöntemi kullanılmıştır.
\end{abstract}

Anahtar Kelimeler: WEB Uygunluk, Göz İzleme, Site Kullanışl11ık Seviyesi, İnsan - Bilgisayar Etkileşimi

\section{WEB COMPLIANCE ANALYSIS: COMPARISON OF HEPSIBUURADA.COM AND N11.COM}

\begin{abstract}
Eye tracking involves measuring where the person viewing a web page is focused on the eye or the movement of the eye. The purpose of eye tracking is to reveal where the site visitors look on the relevant site, how long they look, how long they look at the length of the page. The model of the research is a case study and the usefulness comparisons of n11.com and hepsiburada.com sites, which are exchanged online, are examined. Within the scope of the study, the necessity of trying to buy deep freezers by entering these two different sites was given to the 19 people between the ages of 25 and 45 and the application was made. After opening the web page http://www.n11.com or http://www.hepsiburada.com from the page encountered on the internet, first examining the home page and immediately after reaching the page with the freezers and examining the Beko Brand Deep Freezers, then Beko 7216 A + 5 Drawer freezer page with DF code has been requested to open and review the product. Afterwards, the page was requested to be closed after finishing, as if you would add the product to the basket and take it to the operations. In our study, eye tracking method was used as the analysis method.
\end{abstract}

\footnotetext{
${ }^{1}$ Dr. Öğrt. Üyesi, İstanbul Gelişim Üniversitesi, Uygulamalı Bilimler Yüksek Okulu, Halkla İlişkiler ve Reklamcılık Bölümü, e-posta: seyice@ gelisim.edu.tr
} 
Keywords: WEB Compliance, Eye Tracking, Site Usability Level, Human - Computer Interaction

\section{GİRIŞ}

Günümüz internet dünyasında, birçok ihtiyacımızı web siteleri üzerinden hızlıca gerçekleştirebiliriz. Özellikle son dönemlerde, e-ticaret sitelerinden gerçekleştirilen alışverişler (market, gıda, hizmet), bankacılık işlemleri ve bunun gibi pek çok alanda kullanıcıların ihtiyaçlarını karşılamaya yönelik hazırlanmış olan uygulamalar web uygulamaları şeklinde isimlendirilmektedir.

İnternet kanalıyla satış yapan alışveriş sitelerine bakıldığında, birbirlerinden tamamen farklı ya da benzer yanları olan yüzlerce web uygulamasının kullanıcılara sunulduğu görülmektedir. Böylelikle de aynı hizmet ağını kullanıcısına sunan pek çok web uygulamasının varlığı, kullanıcılar açısından tercih etme ihtimal aralığını oluşturmaktadır. Kullanıcıların tercihlerinin yoğunlaştı̆̆ı sitelerde web uygunluklarının olması bir imkânken diğer birçok alışveriş sitesindeki kullanıcının memnuniyetinin az olduğu ya da sitelerin web uygunlukla ilgili herhangi bir analiz yapmadıkları görülmektedir. Birçok internet sitesi, tercih edilme aralıklarını arttırmak için uygulamaları üzerinde düzenli geliştirmeler ve iyileştirmeler yapmaktadır.

Kullanılabilir olma durumu insanlarla bilgisayarlar arasındaki var olan etkileşimin en temel konularından biridir. Uygulamalar üzerinde ne gibi geliştirmelerin ya da iyileştirmelerin olacağını gösterebilmek adına web kullanılabilirlik testleri, sitelere uygulanmaktadır. Yapılan testlerin sonucuna göre de gerekli görülen aksiyon kalemleri belirlenmekte ve gelen kullanıcı sayısının artması açısından da canlıya alınmaktadır.

Yapılan alan yazın taramaları göstermektedir ki; şimdiye dek kullanılabilirlik testleri bağlamında; kullanıcı deneyim anketleri (Tullis \& Stetson, 2004, s.11) (Velez vd., 2014, s.186) yüksek sesle düşünme protokolü (Akıncı \& Çağıltay, 2004, s.4 ) (Bruun \&Stage, 2015, ss.160-162 ) (Weichbroth vd., 2016, s.1682) gibi yöntemlerle yapılmıştır. Yine bu yöntemler arasında gösterilen göz izleme teknolojisi de kullanılabilirlik açısından ciddi bilgiler sunmaktadır (Becker, 2004, s.388). Göz izleme teknolojisinin, günümüz koşullarında donanımsal ve yazılımsal alanlarındaki gelişmeler 1şığında, eskiye oranla çok daha iyi seviyelere geldiği görülmektedir (Kim, Thomas, \& Yoon, 2015, s.530). Göz izleme donanımları kullanıcılardan elde edilen göz izleme sonuçlarının araştırmacıya kolaylıkla aktarılmasını sağlayarak, araştırmacının uygulamayı değerlendirilmesine olanak tanımaktadır. Bu donanımların sağlamış olduğu bilgiler ve kullanım kolaylıkları nedeniyle de göz izleme teknolojileri, insan bilgisayar etkileşimi alanındaki çalışmalara büyük katkı sunmaktadır (Yeni \& Esgin, 2015, s.600).

Bir katılımcı bir web sayfasına bakarken, göz izleme cihazı katılımcıların gözünün göz bebeğine odaklanır ve bakışlarının yönünü ve konsantrasyonunu belirler. Yazılım bu eylemler hakkında 1sı haritaları ve yolları şeklinde veri üretir: Isı haritaları, ziyaretçinin bakışlarını nereye yoğunlaştırdığını ve belirli bir noktaya ne kadar süre baktıklarını gösterir. Genel olarak, maviden kırmızıya hareket eden bir renk skalası odaklama süresini gösterir. Bu nedenle, sayfanın bir alanı 
üzerindeki kırmızı bir nokta, bir katılımcının veya bir katılımcı grubunun sayfanın bu bölümüne daha uzun bir süre odaklandığını gösterebilir.

Bu makale çalışmasının konusu n11.com ve hepsiburada.com gibi alışveriş sitelerinin, müşteriler tarafından göz izleme metodu ile web uygunluk analizinin yapılmasıdır.

\section{Kavramsal Çerçeve}

Kızı̈ötesi görüntüleme tekniklerinden biri olan termografi, elektromanyetik 1şınımı tespit eder ve bu ışınımdan görseller oluşturur. Termografi kelimesi termal görüntüleme ya da termal video şeklinde de ifade edilir. (Çalışan \& Türkoğlu, 2011, s.46). Duygu derinliklerini ve fizyolojik farklı1ıkları tespit etmek için daha çok yalan makinesinde kullanılan bu yöntem göz izleme cihazlarında tercih edilmezken, termal görüntüleme yoluyla kornea hareketlerini izlemenin teorik olarak mümkün olmasından yola çıkarak, Wang vd. (2016:307) yaptıkları çalışmada kızı̈ötesi termografi yöntemine dayanan yeni bir göz izleme sistemi kurmuşlardır. Wang ve diğerleri (2016), sistemlerini doğrulamak adına 10 denek ile video görüntüleme (Eye Link, $500 \mathrm{~Hz}$ ) ve termografi $(60 \mathrm{~Hz})$ yöntemlerini, eş zamanlı kullanarak göz hareketlerini kaydetmişlerdir.

Böylelikle yayılan termal ısıya dayalı yeni bir göz izleme sisteminin gelecekteki çalışmalar için bir zemin oluşturmasına olanak tanınmıştır. İnsan - bilgisayar etkileşimleri sırasında özellikle web uygunluk analizlerinde uyarıcı ile algının arasındaki ilişkinin bilimsel araştırmalarında göz izleme yöntemi ile kullanılmasına (Gescheider,1997, s.ix) katkı sağlamaktadır.

Termografi, bir kişinin duygusal durumunu anlamak için solunum hızını izleyerek fizyolojik değişiklikleri ortaya çıkacak şekilde başarılı olarak uygulanmaktadır. Bu nedenle, termal ayrışma, multimodal veriler elde etmek için umut verici bir teknik haline gelmiştir.

Efron, Young ve Brennan'e (1989:902) göre kornea kenarı göz bebeği merkezinden $0.45^{\circ}$ daha sicaktır ve bu termal ayreksiyonun geliştirilmesinin temelini oluşturmaktadır. $\mathrm{Bu}$ sistem deneklerin fizyolojik değişikliklerini eş zamanlı olarak izlerken, göz hareketleri ve göz kırpma tepkilerini toplamak için de kullanılabilinir. Böylelikle katılımcıların bilgisayar ekranında nereye baktıklarını izlemek için günümüzde kullandığımız kalibrasyon yaklaşımının temelleri atılmıştır.

Shillcock ve Wase'in (2015:43) yapmış oldukları çalışmada video ile kaydettikleri psikoloji dersini 231 öğrenciye izletmiş ve görsel dikkatlerini göz izleme yöntemi ile incelemişlerdir. Bu yöntemin sonuçları öğrenci öğrenme analitiklerinde yeni ortaya çıkan bir firsat olarak değerlendirilmektedir.

Shillcock ve Wase'in (2015) makalesini referans göstererek benzer bir deney de Bielecki vd. (2017:103 ), tarafindan Varşova'daki Kopernik Bilim Merkezi'2nde planetaryum ziyaretçilerine yapılmıştır. Bilim merkezinin kubbesinin altında gerçekleştirilen canlı sunumlar sırasında 2 deney (16 metrelik yarım küre ekranı kullanarak) göz izleme yöntemi kullanılarak uygulanmıştır. Deneyde görsel dikkat analizi yapılmışır ancak bu sonuçlar göstermektedir ki deney saha araştırmaları için uygun değildir. 
Okülomotor davranışlarının en doğal, günlük koşullarda incelenmesi, birçok görsel dikkat araştırmacısının hayalidir (Siegfried \& Odobez, 2017, s.2).

Mora ve Odobez'e (2014:1780) göre dikkat ve ilginin bir göstergesi olarak bakış, insanların davranışlarını anlamanın temelini oluşturan ipuçlarından biridir. Bu nedenle birçok araştırma ve uygulamada önemli bir rol oynar. İnsan- robotik etkileşimi (HRI) ve İnsan -bilgisayar etkileşimi arayüzler de başta olmak üzere ilgili sistemlerin gelişmesine olanak sağlayacaktır.

Elektromanyetik izleyicilerin çarpıcı bir örneği, göz hareketlerini son derece büyük bir hassasiyetle $\left(0.0002^{\circ}\right.$ ve $8000 \mathrm{~Hz}$ örnekleme oran1) kaydedebilen İsviçre primelec airtrekerleridir. Çalışma prensibi, manyetik alanda metal bir devrenin hareket etmesinden kaynaklanan elektrik akımının indüksiyonu üzerine kurulmuştur. Hareketli parça bir kontakt lens gibi, göze takılan iki dahili endüktans döngüsüne sahip bir halkadır. Bu tür cihazların yardımıyla, sıfır yerçekimindeki astronotlardaki değişiklikleri de dahil olmak üzere, gözlerin mikro hareketlerinin çeşitli özelliklerini incelenebilinir (Bielecki vd., 2017, s.103 ).

Elektrookülogram (EOG), göz hareketi sırasında oluşan elektriksel aktiviteyi kaydetmek için kullanılan bir yöntemdir. Gözün korneası retinaya göre pozitif bir yüke sahip olduğundan, bu kalıcı (korneoretinal) bir potansiyel oluşturur. Gözün konumu değiştiğinde, bu potansiyelin ayarlanması gerçekleşir. EOG, oküler yarığın burun ve temporal köşesine yatay ve dikey sakkadları kaydetmek için kaşın üstünde ve gözün altında bulunan elektrotlar tarafindan kaydedilir. Bu yöntem hala tıbbi uygulamada, bazen EEG yöntemi ile birlikte yaygın olarak kullanılmaktadır (Al-Khalidi , vd., 2011, s. 588).

$\mathrm{Bu}$ yöntemle, kullanıcının ilk etapta neye dikkat ettiği ve son olarak neye dikkat ettiği izlenmektedir. Bu, kullanıcıların sitenin arayüzünü ne kadar anladığını değerlendirmemizi sağlar. Bir kişi istenen öğeyi hızlı bir şekilde bulursa, arayüz uygundur. Eğer bulamıyorsa arayüz kullanılabilirliği zayıftır ve tekrar tasarım değişikliğine gidilebilir.

Gerçek şu ki, internette hesap erişimleri saniyeler sürmektedir. Çoğu durumda, kullanıcı siteyi ilk 30 saniye içinde anlamadıysa, o zaman o siteden hızla ayrılır. Bu, tasarımın mümkün olduğu kadar açık olması gerektiği anlamına gelir, önemli unsurlar hemen göze çarpmalı ve bilgiye kısa sürede ulaşılmalıdır.

\section{Yöntem}

\section{Araştırmanın Amacı}

Çalışmanın amacı, aynı ürünü satan benzer internet sitelerinden hangisinin daha kullanılabilir olduğunu, gerçek kullanıcılar kullanılarak göz izleme yöntemi ile tespit etmek ve kullanıcı davranışları açısından değerlendirilmesini sağlamaktır.

\section{Araştırmanın Önemi}

Çalışma kapsamında, kullanıcı odaklı web sitesi tasarımlarının kolay kullanılabilirliği, göz izleme yöntemi kullanılarak sıcaklık haritası görsel gösterimi ile analizlenmiştir. Araştırmacılar göz 
izleme yöntemi sayesinde bazı internet sitelerinin neden işe yaramadığını tespit edebilmekte böylece tasarım aşamasında sayfa düzeni, resim ve fotoğraf kullanımı, yazı karakterleri ve gezinme menülerine müdahale ederek internet sitelerinin tasarımlarında yapılan hataları en aza indirebilmektedir. $\mathrm{Bu}$ yönde yapılan uygulama tasarımcıların ve reklamcıların faydalanması açısından önemlidir.

\section{Araştırmanın Sınırlılıkları}

Çalışma İstanbul ili ile sınırlıdır ve 2019 yılında gerçekleştirilmiştir.

\section{Araştırmanın Yöntemi}

Bu makale çalışması, 25 - 45 yaş aralığında bulunan 19 kişi ile yapılmıştır. Deney esnasında, denek gruplarından hepsiburada.com ve n11.com sitelerinde yer alan aynı ürünün internet sitesi üzerinden satın alma işleminin yapılması istenmiştir. Araştırmada her iki web sayfası için 2 farklı deney senaryosu uygulanmıştır. Deney senaryosunun ilkinde, derin dondurucu alınmak istenildiği varsayılarak internet ortamında karşılaştığınız sayfadan alışveriş yapılması istenilen web sayfasının açılması, açılan ana sayfanın incelenmesi, hemen akabinde, derin dondurucuların bulunduğu sayfaya ulaşılıp sayfada yer alan Beko Marka Derin Dondurucuların tamamının incelemesi ve sonra Beko 7216 DF kodlu A+ 5 Çekmeceli derin dondurucuyu seçerek dondurucunun sayfasının açılması ile birlikte ürünün özeliklerinin incelenmesi istenmiştir. Daha sonra deneklerden ürünü sepetlerine ekleyip işlemlerine satın alacaklarmış gibi devam etmeleri ve işlemi bitirdikten sonra sayfayı kapatmaları talep edilmiştir.

İkinci deney senaryosunda ise deneklerden, karşılarına çıkan sayfadan alışveriş yapılması istenilen internet sitesi açıldıktan sonra önce ana sayfanın incelenmesi, daha sonra arama butonundan Beko 7216 DF kodlu A+ 5 Çekmeceli derin dondurucuna ulaşılmaya çalışılması, sayfayı bulduktan sonra ürünün incelenmesi istenmektedir. Ürünü inceledikten sonra ürünü sepete ekleyip işlemlere alacakmışsınız gibi devam etmeleri istenmektedir. Ayrıca çalışmanın geçerliliğinin ve güvenilirliğinin sağlanması için deneye başlamadan önce deneklere tek tek ön test soruları yöneltilmiştir ve göz izleme yöntemi uygulandıktan sonra deneklere tek tek son test soruları yöneltilmiştir. Böylelikle analiz sonuçları desteklenmiştir. Çalışmada analiz metodu olarak göz izleme yöntemi kullanılmıştır.

\section{n11.com 1-Deney Senaryosu}

Bir derin dondurucu almak istiyorsunuz. Karşınıza çıan sayfadan http://www.n11.com web sayfasını açtıktan sonra önce ana sayfayı inceleyiniz, derin dondurucuların bulunduğu sayfaya ulaşıp Beko Marka Derin Dondurucuları inceledikten sonra Beko 7216 DF kodlu A+ 5 Çekmeceli derin dondurucu sayfasını açınız ve ürünü inceleyiniz. Daha sonra ürünü sepete ekleyip işlemlere alacakmışsınız gibi devam edeniz. Bitirdikten sonra sayfayı kapatınız.

\section{n11.com 2-Deney Senaryosu}

Bir derin dondurucu almak istiyorsunuz. Karşınıza çıkan sayfadan http://www.n11.com web sayfasını açtıktan sonra önce ana sayfayı inceleyiniz. Daha sonra arama butonundan Beko 7216 
DF kodlu A+ 5 Çekmeceli derin dondurucuna ulaşmaya çalışınız, sayfayı açınız ve ürünü inceleyiniz. Daha sonra ürünü sepete ekleyip işlemlere alacakmışsınız gibi devam ediniz. Bitirdikten sonra sayfayı kapatınız.

\section{hepsiburada.com 1-Deney Senaryosu}

Bir derin dondurucu almak istiyorsunuz.

Karşınıza çıkan sayfadan www.hepsiburda.com web sayfasını açtıktan sonra önce ana sayfayı inceleyiniz, derin dondurucuların bulunduğu sayfaya ulaşıp Beko Marka Derin Dondurucuları inceledikten sonra Beko 7216 DF kodlu A+ 5 Çekmeceli derin dondurucu sayfasını açınız ve ürünü inceleyiniz. Daha sonra ürünü sepete ekleyip işlemlere alacakmışsınız gibi devam ediniz. Bitirdikten sonra sayfayı kapatınız.

\section{hepsiburada.com 2-Deney Senaryosu}

Bir derin dondurucu almak istiyorsunuz. Karşınıza çıkan sayfadan www.hepsiburda.com web sayfasını açtıktan sonra önce ana sayfayı inceleyiniz Daha sonra arama butonundan Beko 7216 DF kodlu A+ 5 Çekmeceli derin dondurucuna ulaşmaya çalışınız, sayfayı açınız ve ürünü inceleyiniz. Daha sonra ürünü sepete ekleyip işlemlere alacakmışsınız gibi devam edeniz. Bitirdikten sonra sayfayı kapatınız.

\section{n.11.com ve hepsiburada.com Web Sitelerinin İlk Test Soruları}

1) İnternetten alışveriş yapar mısınız?

2) Aktif kullanıcı misınız?

3) Daha çok neler almayı tercih edersiniz?

4) Elektronik ürünleri internet üzerinden satın alır mısınız?

5) İnternetten belli bir ürün ve belli bir marka satın alacaksanız kısa yolları (arama butonu) kullanmayı tercih eder misiniz?

6) Elektronik ürünleri hangi internet sitelerinden satın alıyorsunuz?

7) Sizce elektronik ürünleri alacağınız internet sitesi nasıl olmalıdır?

\section{Son Test n11.com Web Sitesi Soruları}

1) n11.com sitesini incelediniz, ürün ve fiyat bilgileri sizin için yeterli geldi mi?

2) Web sitesi beklentilerinizi karşıladı mı?

3) İnternet sitesini beğendiniz mi?

4) İnternet alışverişlerinizde kullanmayı tercih eder misiniz? 


\section{Son Test hepsiburada.com Web Sitesi Soruları}

1) hepsiburada.com sitesini incelediniz, ürün ve fiyat bilgileri sizin için yeterli geldi mi?

2) Web sitesi beklentilerinizi karşıladı mı?

3) İnternet sitesini beğendiniz mi?

4) İnternet alışverişlerinizde kullanmayı tercih eder misiniz?

\section{n11.com ve hepsiburada.com Son Test Ortak Soruları}

1) İki farklı yöntem kullanarak derin dondurucu sepete eklediniz. Sizce hangi yöntem daha kullanışlıydı?

2) İki farklı internet sitesinden aynı derin dondurucuyu almaya denediniz. Sizce hangi web sitesi daha başarılıydı?

\section{Göz İzleme Yöntemi}

Göz izleme yöntemi gözün hangi yolları izleyerek nereye baktığını, ne zaman ve ne kadar baktığını göz izleme cihazı yardımıyla tespit eder. Verilerin daha net anlaşılmasını sağlamak için verinin görselleştirilmesinde bazı yöntemler kullanılmaktadır. Bu yöntemler: Tarama Yolları (Scanpath), Sicaklık Haritaları (Heatmap) ve Focus Haritalarıdır. (Focus Map)

Tarama Yolları: Arı Sürüsü de denilmektedir. Deneklerin nereye daha fazla odaklandıkları ve bu bölgelere hangi sıra ile baktıklarını ifade ederken, her bir renk farklı bir kişiyi ifade eder. Tek tek gösterilebildiği gibi deneklerin toplu gösterimi de yapılabilir.

Sıcaklık Haritaları: Isı haritaları ya da sıcaklık bölgeleri şeklinde de ifade edilir. Odaklanılan yoğun bölgeleri renklerle ifade eder. En dikkat çekici ve odaklanılan bölge kırmızı renkle temsil edilir. Yeşil, sarı ve turuncu renkleri ile de yoğunluk derecelendirilmiştir.

Focus Haritaları: Odaklanma haritası da denilir. Odaklanılan bölgeler aydınlıkta diğer bölgeler karanlıkta kalmaktadır.

Göz izleme analizleri 3 farklı cihaz yardımıyla verileri toplar. Bunlar; başa takılan, masa üstüne monte edilen ve gözlük şeklinde olan araçlardır. Bu araştırmada masa üstü modeli kullanılmıştır.

\section{Araştırmanın Evreni ve Önemi}

Araştırma, 25 - 45 yaş aralığında 19 kişi ile A-B SES düzeyinde, İstanbul'da yaşayan, ailesi en az lise düzeyi eğitimli, teknolojik gelişmelere uzak olmayan (bilgisayar, internet, facebook, twitter, vs.), açık görüşlü, yeniliklere adapte olabilen, trendleri takip eden, ekonomik düzeyleri hepsiburada.com ve n11.com sitelerinden alışveriş yapmaya uygun, hepsiburada.com ve n11.com sitelerini daha önce kullanmış deneklerle, SMI marka göz izleme cihazı kullanılarak sesi, gürültüyü ve 1şığı geçirmeyen özel olarak tasarlanmış deney odasında, NeuroByte.co araştırma şirketinde yapılmıştır. 


\section{Bulgular}

\section{İlk Test Sonuçları}

\section{1) İnternetten alışveriş yapar mısınız?}

19 kişi ile yapılan deneylerde deneklerin tamamı internetten alışveriş yaptığını belirtmiştir.

\section{2) Aktif kullanıcı mısınız?}

19 kişiden sadece 3 tanesi interneti aktif olarak kullanmadıklarını belirtmişlerdir.

\section{3) Daha çok neler almayı tercih edersiniz?}

Denekler daha çok moda ürünleri satın almayı tercih ettiklerini belirtirken sıralamayı şu şekilde yapmışlardır. Moda- Kozmetik- Teknoloji- Elektronik- Süpermarket

\section{4) Elektronik ürünleri internet üzerinden satın alır mısınız?}

Deneklerin tamamı internet üzerinden elektronik ürün satın aldıklarını belirtmişlerdir.

5) İnternetten belli bir ürün ve belli bir marka satın alacaksanız kısa yolları (arama butonu) kullanmayı tercih eder misiniz?

Deneklerin 8 tanesi kısa yolları tercih ederken diğerleri alıştıkları sırayla ve yöntemle daha kolay işlemlerini yaptıklarını savunmaktadır.

6) Elektronik ürünleri hangi internet sitelerinden satın alıyorsunuz?

7 kişi 'hepsiburada.com' ve 'hızlial.com' sitelerini söylerken 5 kişi n11.com 4 kişi gittigidiyor.com, 3 kişi akakce.com isimli siteleri kullandıklarını belirtmişleridir.

7) Sizce elektronik ürünleri alacağınız internet sitesi nasıl olmalıdır?

Deneklerin kullanmakta olduğu internet sitelerinden beklentileri şunlardır:

- Açıklamaların net, anlaşı1ır ve yeterli olması

- $\quad$ Fiyat ve ödeme seçeneklerinin ürünün altında yer alması

- Sade olmas1

- Kolay kullanılmasi

\section{Göz İzleme Analizi}

\section{Deney Tasarısı (n11.com sitesi için ana menünün bulunduğu açılış sayfası)}

Deneklerin tamamının web sayfasında bulunan menü kısmını inceledikleri ve yazıları soldan sağa ve yukarıdan aşağıya doğru okudukları gözlemlenmiştir. Navigasyon menüsünden verilen 
senaryo okunduktan sonra kolay bulunabildiği ve sayfanın geri kalanında gözlerin çok fazla dağılmamış olduğu gözlemlenmiştir.

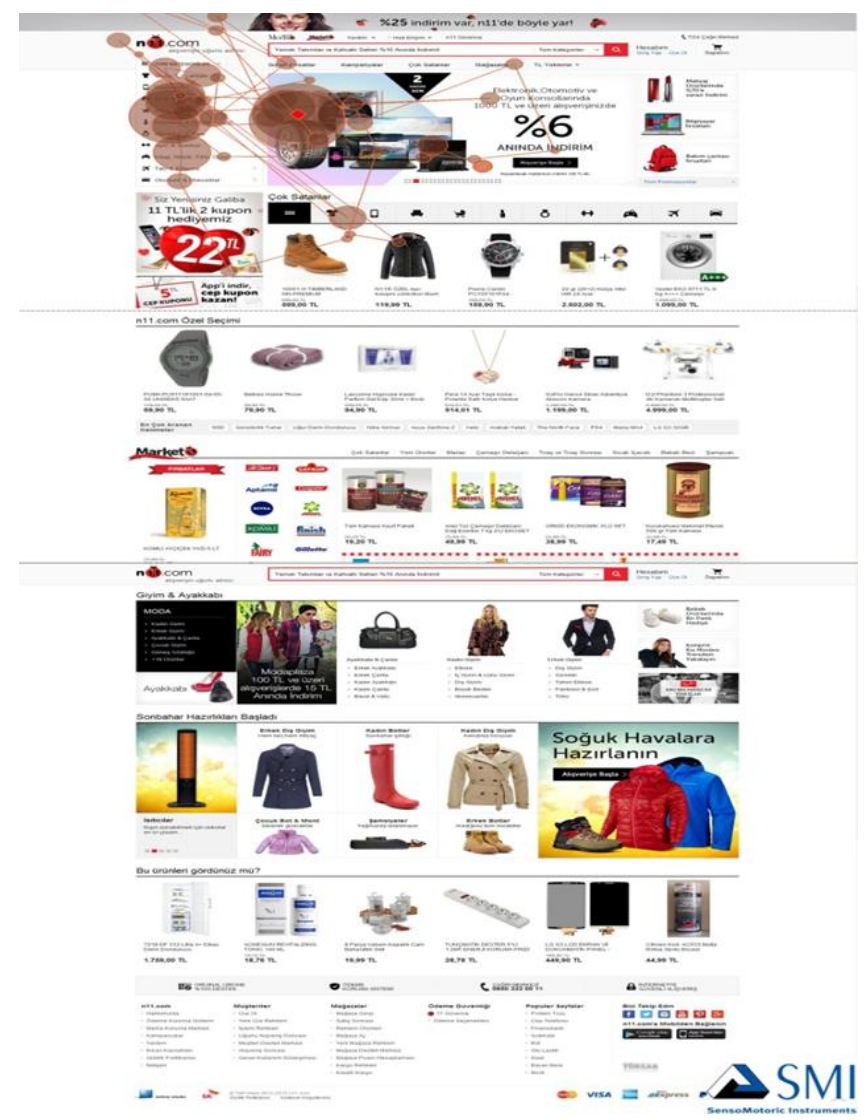

Resim 1.n11.com İnternet Sitesi Ana Menü

Yukarıda resim 1'deki scanpath'lerde (tarama yolu) görüldüğ̈̈ üzere odaklanan noktaların 'Tüm Kategori' ana başlı̆ğ altında yer alan yazıların olduğu ve yazıların yukarıdan aşağıya doğru okunduğu belirlenmiştir.

'Elektronik' başlığı üzerine gelindiğinde, sağ tarafa doğru alt kategorilerin açıldığı ve odaklanmanın o yöne doğru ilerlediği görünmektedir. Kategorilerin açılmış halleri toplanan datalarda sayfa yapısından ötürü gözükmemektedir. Fakat bakış yolu açılan yerin üzerindedir. İlk olarak 'Elektronik' seçeneğinin üzerine denk gelmektedir. 'Beyaz Eşya'ya tıklandığ 1 saptanmaktadır (kırmızı kare nokta ile gösterilmiştir). Sayfa üzerinde odaklanmaların dağılmadığı yani bilgilerin kısa sürede, sayfanın başka bölgelerine odaklanılmadan kolaylıkla bulunabildiği görülmüştür.

Aşağıdaki resim 2'deki Heat Map'de ( sıcak bölge haritası) görüldüğü üzere solda yer alan haritada deneklerin 'Beyaz Eşya' başlığı altında yer alan 'Derin Dondurucu' yazısını bulana kadar yukarıdan aşağıya doğru yoğunlaştıkları ve sayfanın geneline dağılmadıkları tespit edilmiştir. 


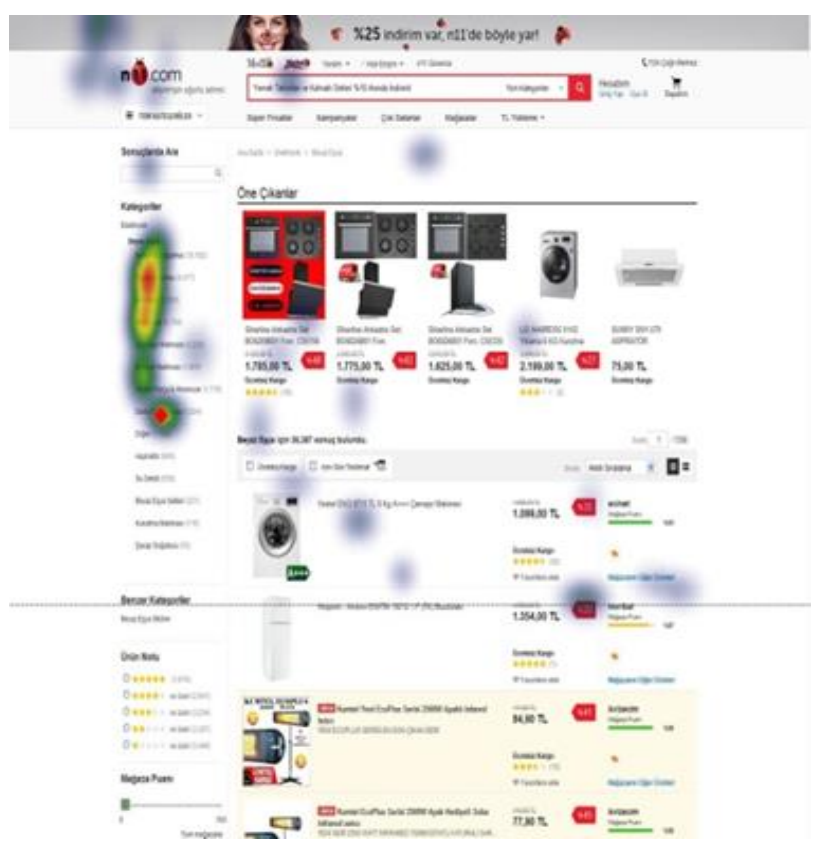

Resim 2. n11.com İnternet Sitesi Beyaz Eşya

Aşağıdaki resim 3'de bulunan Heat Map'de ( sıcak bölge haritası) ise deneklerin ilk olarak sayfadaki derin dondurucuları yukarıdan aşağıya doğru inceledikleri, hemen arkasından markalara yoğunlaştıkları görülmüştür. Beko markasına kadar yoğunlaşmanın devam ettiği ve tıklamanın gerçekleştiği belirlenmiştir.

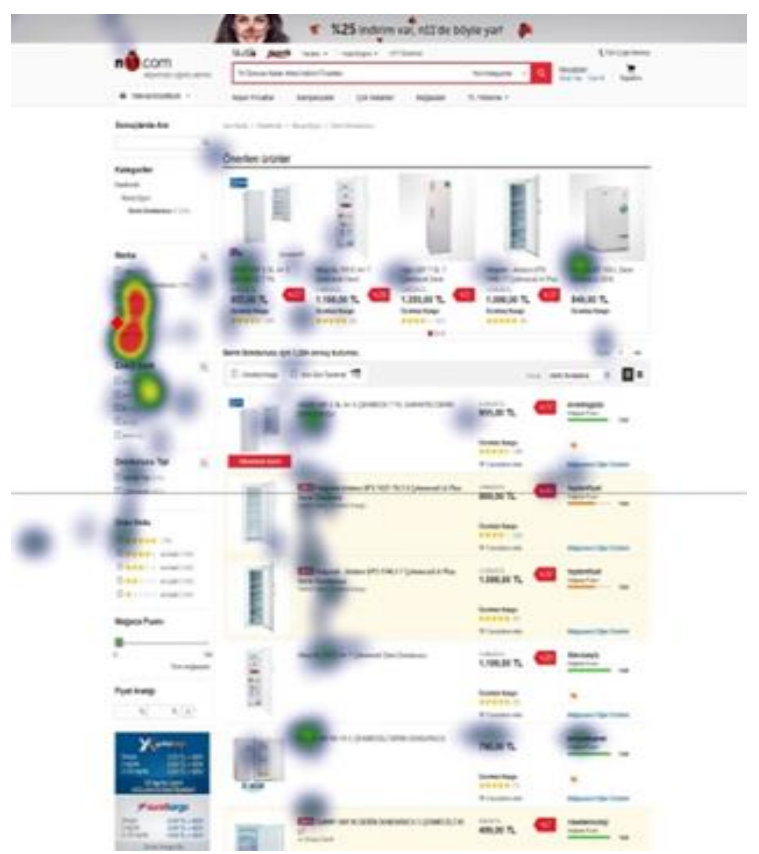


Resim 3. n.11.com İnternet Sitesi Beko

Aşağıdaki resim 4'te yer alan haritada ise Beko derin dondurucu modellerinin tek tek incelendiği, istenilen modele yoğunlaşıldığı ve tıklamanın gerçekleştiği belirlenmiştir. (kırmızı kare nokta)

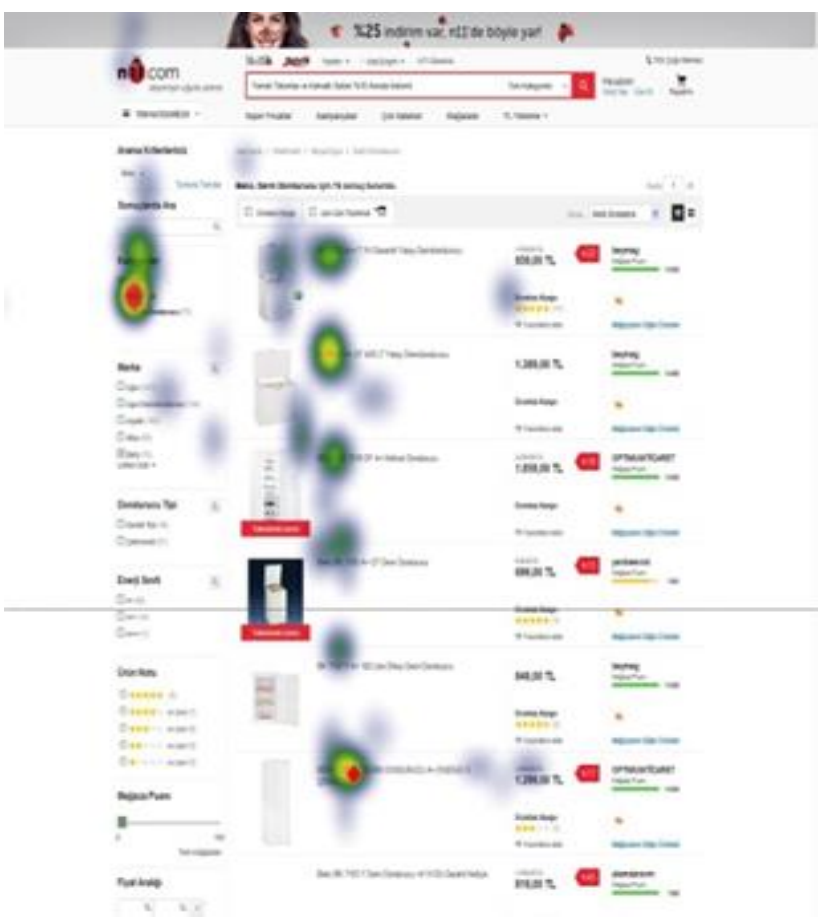

\section{Resim 4. n11.com İnternet Sitesi Beko Derin Dondurucu Modelleri}

Aşağıdaki 5. ve 6. resimdeki Heat Map'lerde (sıcak bölge haritasında) görüldüğü üzere deneklerin hepsinin derin dondurucu ürününü ve özelliklerini inceledikleri saptanmıştır. Deneklerin genelinin 'Sepete Ekle'ye yöneldiği belirlenirken sadece 2 deneğin 'Hemen Al'ı tıkladığı saptanmıştır. Sepete ekle tıklandıktan sonra sol köşe tarafa doğru alt kategorilerin açıldığı ve odaklanmanın o yöne doğru ilerlediği görülmüştür. Kategorilerin açılmış halleri toplanan datalarda sayfa yapısından ötürü gözükmemektedir. Fakat bakış yolu açılan yerin üzerindedir ve tıklama noktası da ilk olarak 'Sepete Git' seçeneğinin üzerine denk gelmektedir. 

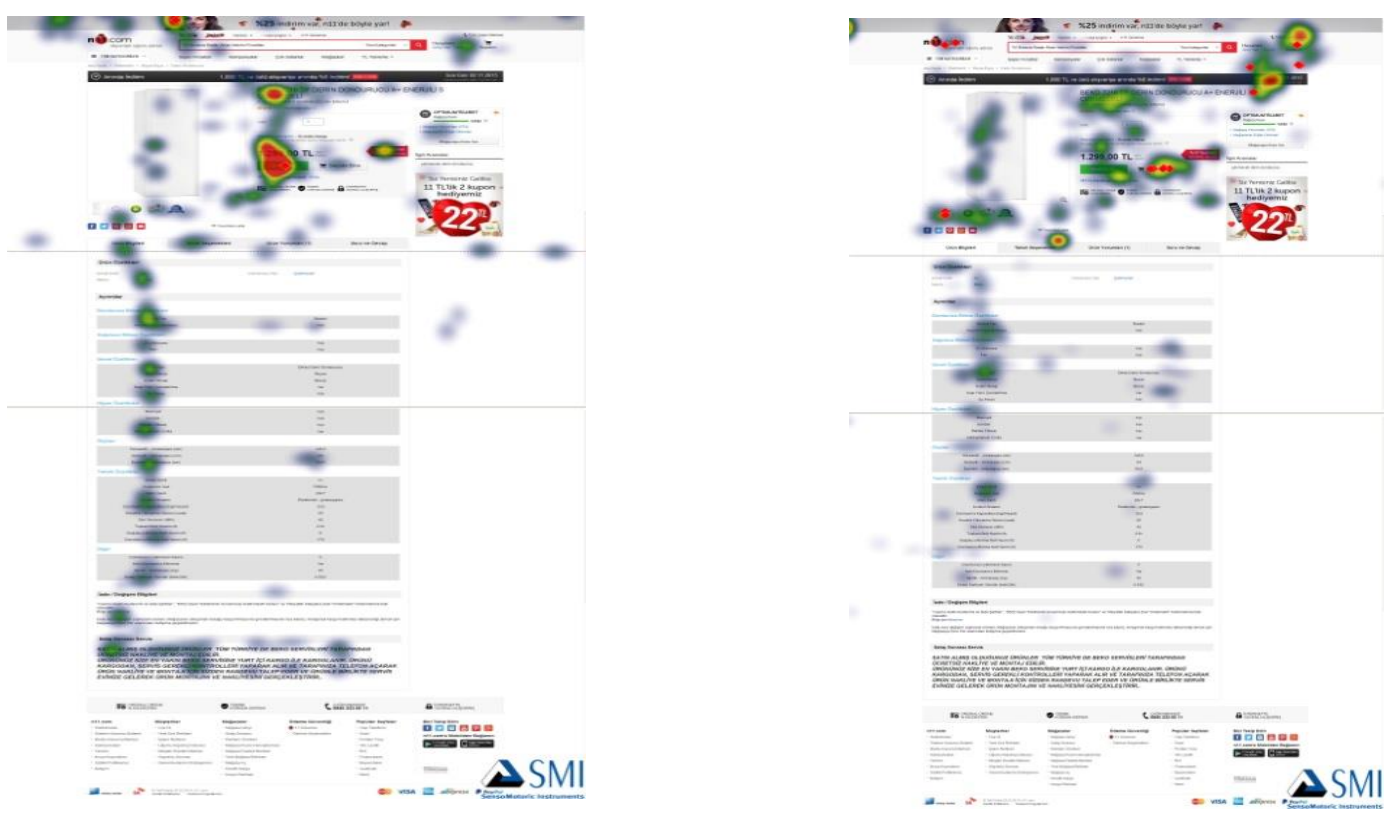

Resim 5. n.11.com İnternet Sitesi Sitesi Sepete Ekle Resim 6. n.11.com Sitesi Hemen Al

Aşağıda bulunan resim 7'deki haritada görüldüğü üzere yoğunlaşmaların teker teker 'Model', 'Kargo', 'Fiyat' ve 'Satın Al' başlıklarında olduğu belirlenmiştir. En fazla yoğunlaşmanın ise 'Model' ve 'Satın Al' da olduğu gözlemlenmiştir.

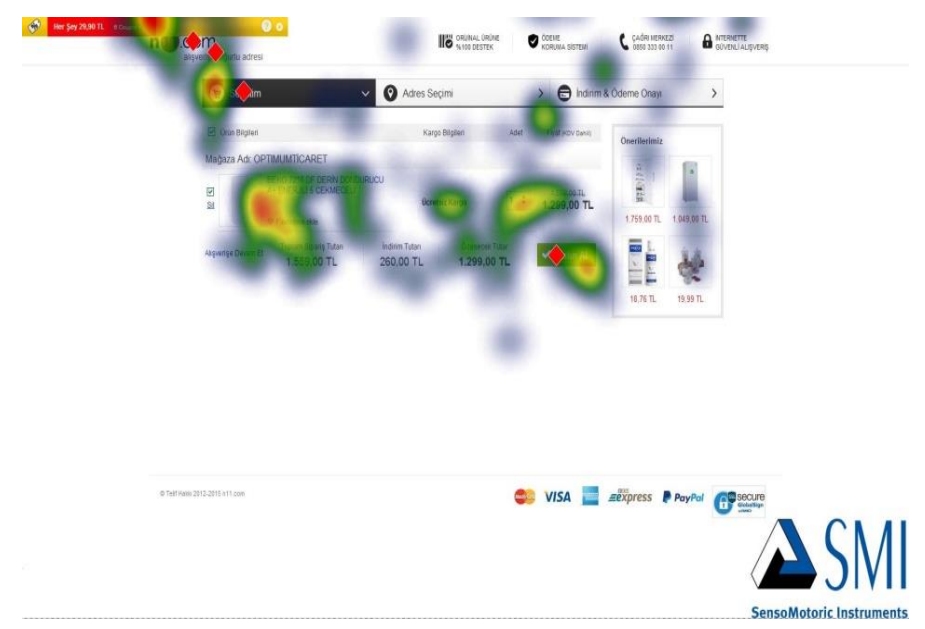

Resim 7. n11.com İnternet Sitesi Model ve Satın Al

\section{2-Deney Senaryosu}

Deneklerden arama butonu kullanarak 'Beko 7216' derin dondurucuya ulaşmaları istenildiğinde deneklerin sayfada hiç vakit kaybetmeden, sayfaya dağılmadan sonuca ulaştıkları belirlenmiştir. Aşağıdaki resim 8 ve 9'daki haritalarda görüldügü üzere istenilen derin dondurucunun modeline odaklanıldığı ve ücretsiz kargo'da yoğunlaşıldığı belirlenmiştir. Derin dondurucuya tıklanıldığ 
(kırmızı kare nokta) saptanmıştır. Deneklerin derin dondurucu modeline, hemen al ve sepete ekle butonlarına odaklandıkları ve sepete ekle butonunu tıkladıkları belirlenmiştir. Yukarıdan aşağıya, soldan sağa doğru giden odaklanmamın daha sonra sol köşede yer alan sepette tamamlandığ gözlemlenmiştir.
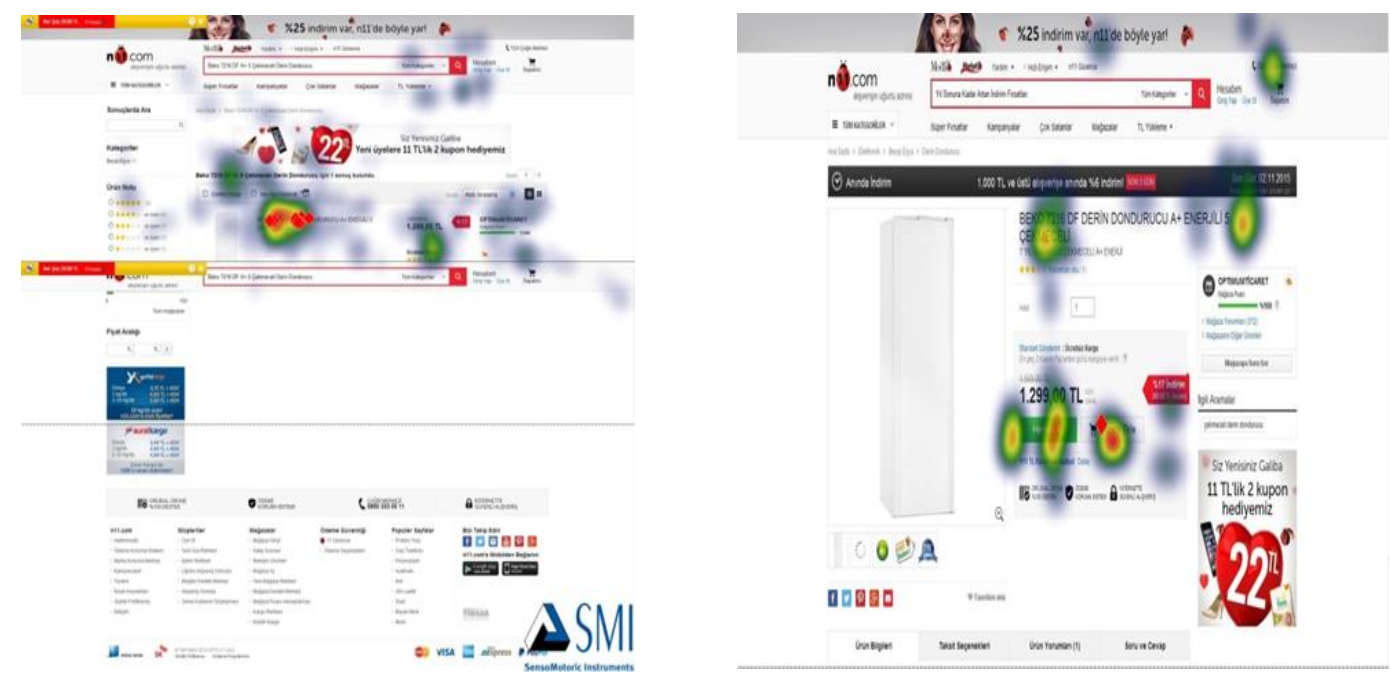

Resim 8. n11.com İnternet Sitesi Beko 7216

Resim 9. n11.com İnternet Sitesi Fiyat

\section{Deney Tasarısı (hepsiburada.com sitesi için ana menünün bulunduğu açılış sayfası)}

\section{Ana menünün bulunduğu açılış sayfası 1. Deney Tasarısı}

Deneklerin tamamının web sayfasında bulunan menü kısmını inceledikleri ve yazıları soldan sağa ve yukarıdan aşağıya doğru okudukları gözlemlenmiştir. Navigasyon menüsünden verilen senaryo okuduktan sonra kolay bulunabildiği, sayfanın geri kalanında gözlerin çok fazla dağılmamış olduğu gözlemlenmiştir. 


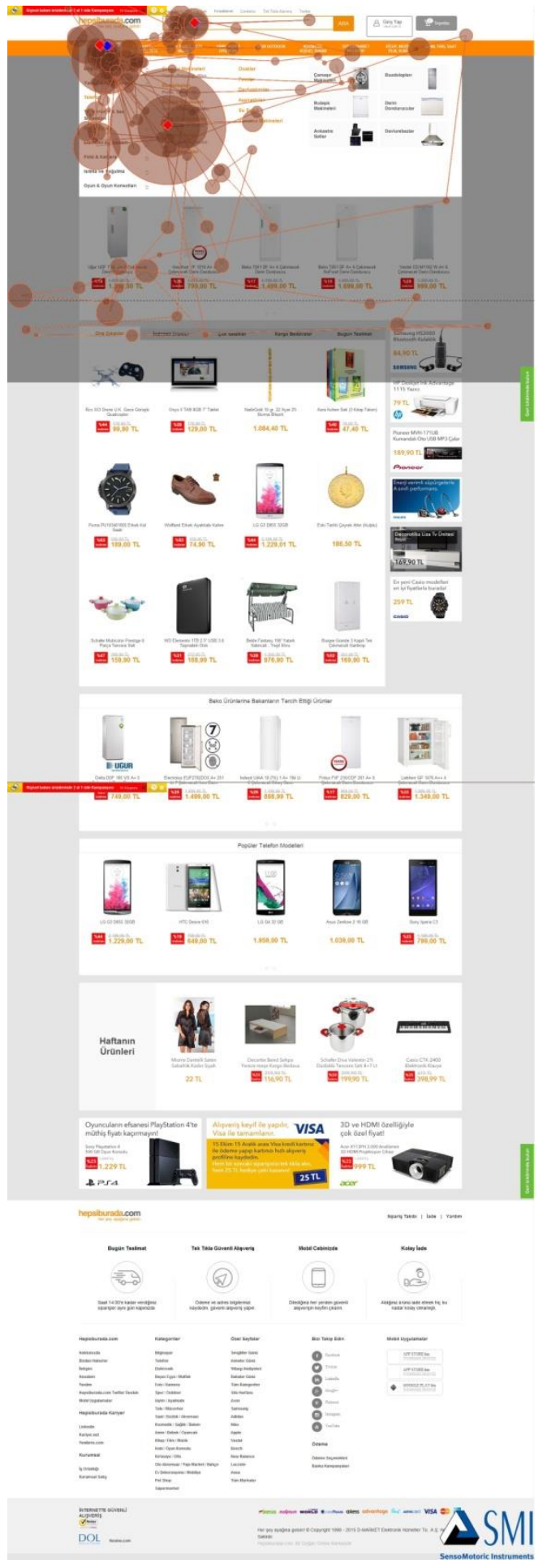

Yandaki resim 10'daki scanpath'lerde (tarama yolu) görüldüğü üzere odaklanan noktaların 'Elektronik' yazısı olduğu ve yazıların yukarıdan aşağıya doğru okunduğu belirlenmiştir. 'Elektronik' başlı̆ğ üzerine gelindiğinde sağ tarafa doğru alt kategorilerin açıldığını ve odaklanmanın o yöne doğru ilerlediği görünmektedir. Kategorilerin açılmış halleri toplanan datalarda sayfa yapısından ötürü gözükmemektedir. Fakat bakış yolu açılan yerin üzerindedir. T1klama noktası da ilk olarak 'Elektronik' seçeneğinin üzerine denk gelmektedir. 'Derin Dondurucu 'ya tıklandığı saptanmaktadır. (kırmızı kare nokta ile gösterilmiştir). Sol çerçevedeki menünün yanı sıra üst çerçevedeki yatay menünün de okunabildiği gözlemlenmektedir. Yine burada da görülen odaklanma noktaları ve tıklama noktaları 'Elektronik' başlığı gelindiğinde açılan menüler üzerindedir. Sayfa üzerinde odaklanmaların dağılmadığı yani bilgilerin kısa sürede, sayfanın başka bölgelerine odaklanılmadan kolaylıkla bulunabildiği görülmektedir.

Resim 10. hepsiburada.com İnternet Sitesi Ana Menü 
Aşağıda bulunan resim 11'deki sayfanın Heat Map'inde (sıcak bölge haritası) tarama yolları haritasından elde edilen bilgilere benzer bilgilere ulaşılmıştır. En çok yoğunlaşılan alanlar, senaryoda verilen ürünün bilgileri üzerinedir. Bilgilerin bulunmasında bir sorun yaşanmadı̆̆ odaklanmaların bilgilerin bulunduğu noktalarda yoğunlaşmaların fazla olmasından anlaşılmaktadır.

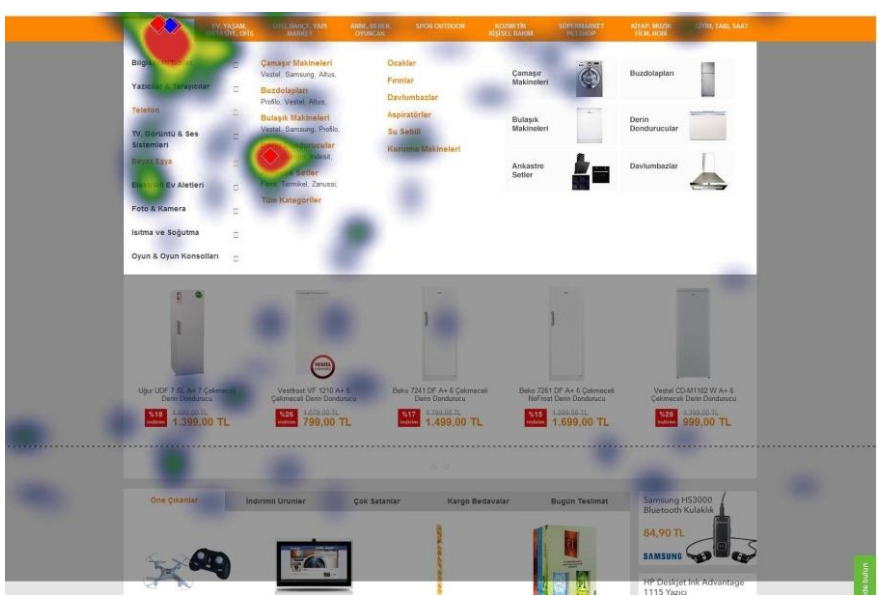

Resim 11. hepsiburada.com İnternet Sitesi Ürün Bilgileri

Aşağıda sol tarafta yer alan resim 12'deki Heat Map'de (Sicak bölge haritası) 'Elektronik' başlığını tıklayan deneklerin yukarıdan aşağıya doğru baktıkları çok vakit harcamadan ve Beko markasını buldukları ve tıkladıkları belirlenmiştir. Sağ tarafta yer alan resim 13 'deki Heat Map'de (Sıcak bölge haritası) görüldüğü üzere Beko markası tıklandıktan sonra solda açılan sayfada istenilen Beko modelini bulmak için soldan sağa yukarıdan aşağıya doğru tek tek bakıldığı ve istenilen modelin kolay bulunduğu ve deneklerin 5 tanesi tarafindan direk sepete eklendiği tespit edilmiştir.

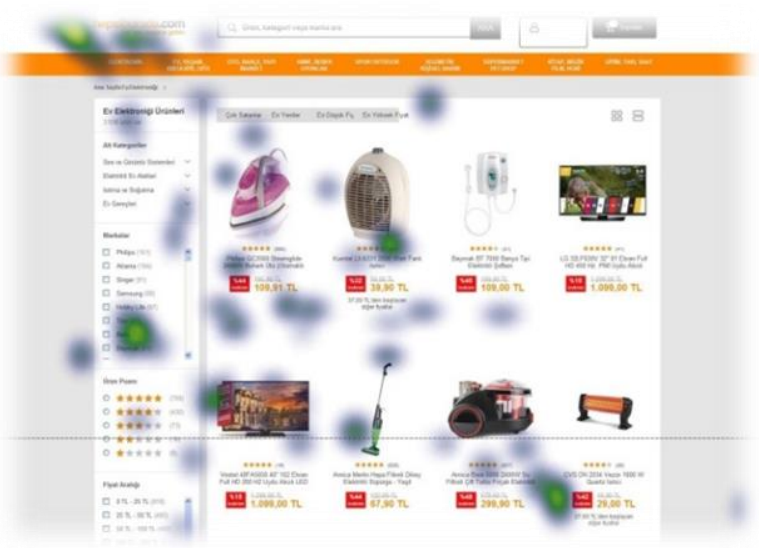

Resim 12.hepsiburada.com İnternet Sitesi Elektronik

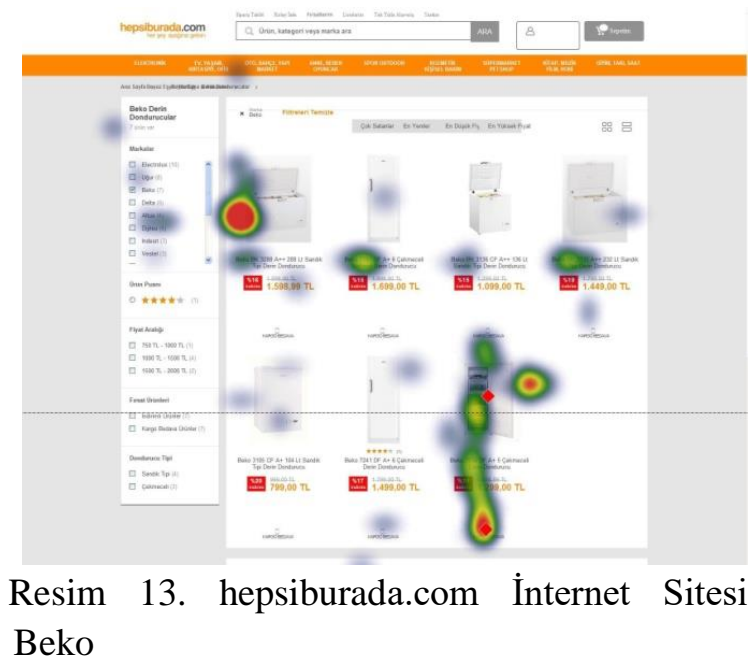



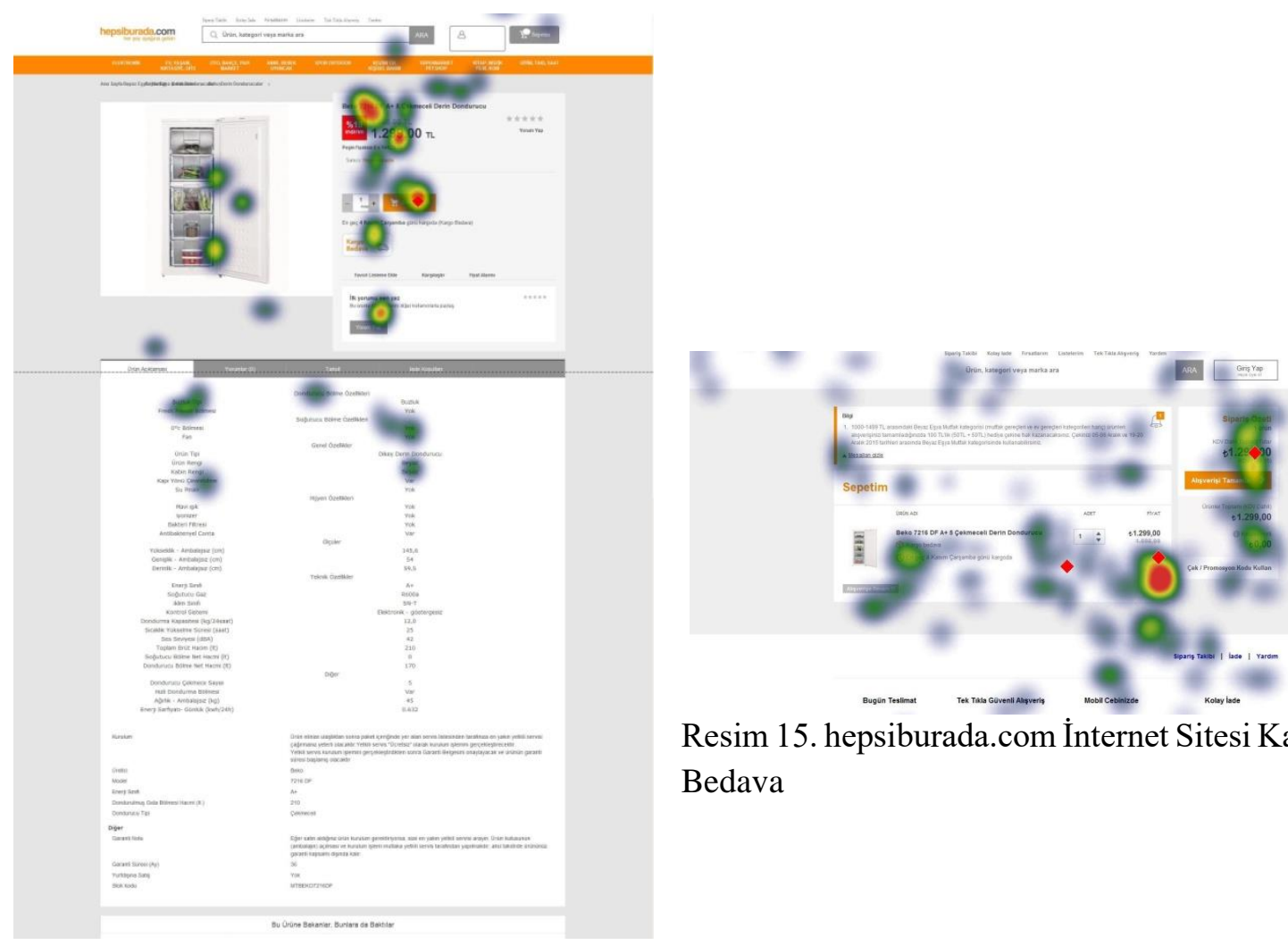

Resim 15. hepsiburada.com İnternet Sitesi Kargo Bedava

Resim 14. hepsiburada.com İnternet Sitesi Model

Yukarıdaki resim 14'deki Heat Map'de ( sıcak bölge haritası) görüldüğü üzere deneklerin ilk olarak derin dondurucuyu incelemeye başladıkları, modeline, fiyatına ve sepete ekleye yoğunlaştıkları tespit edilmiştir. Sepete ekledikten sonra resim 15'deki Heat Map'de ( sıcak bölge haritası) görüldügü üzere deneklerin ilk olarak kargo bedava yazısına ve fiyata odaklandıkları daha sonra sağdan sola doğru önce fiyata sonra alışverişi tamamla butonuna odaklanıldığı belirlenmiştir.

\section{2-Deney Senaryosu}

Deneklerden arama butonunu kullanarak 'Beko 7216' derin dondurucu modeline ulaşmaları istenildiğinde deneklerin sayfada hiç vakit kaybetmeden sayfada dağılmadan sonuca ulaştıkları belirlenmiştir. 


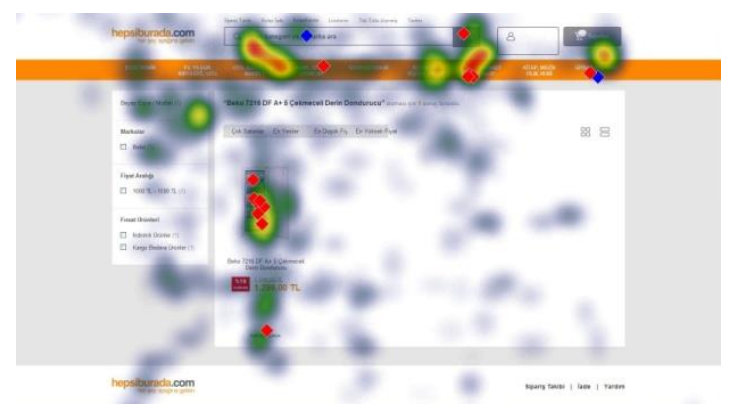

Resim 16. hepsiburada.com İnternet Sitesi Beko 7216

Yukarıda bulunan resim 16'daki haritada görüldüğü üzere arama butonuna 'Beko 7216' yazıldıktan sonra, istenilen modelin sayfada tek çıkmasından dolayı deneklerin sayfanın geneline odaklanmadan direk buzdolabına yoğunlaştıkları görülmektedir.

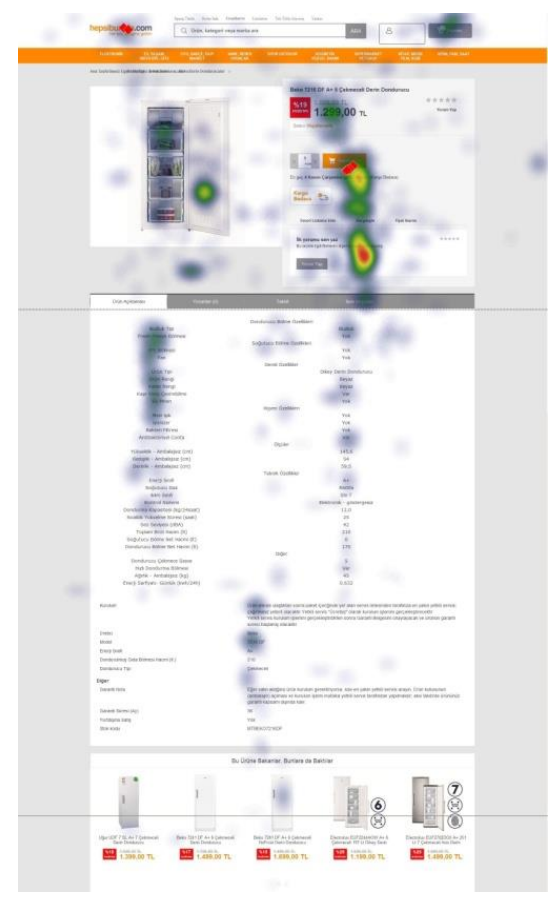

Resim 17. hepsiburada.com İnternet Sitesi Sepete Ekle

Resim 17 'de deneklerin bazılarının kargo bedava yazısının altında kalan sepete ekle seçeneğine geçtikleri belirlenirken geriye kalanların derin dondurucuya tıklayarak (kırmızı kare nokta) buzdolabını yeni bir pencerede açtıkları ve incelemeye o sayfada devam ettikleri gözlemlenmiştir. Ürünün yukarıdan aşağıya, soldan sağa incelendiği belirlendiği gibi modele, fiyata odaklanıldığ 1 odak noktasının en son sepete ekle de kaldığı ve tıklanıldığ 1 (kırmızı kare nokta) ortadaki haritada net bir şekilde gözlemlenmektedir. 


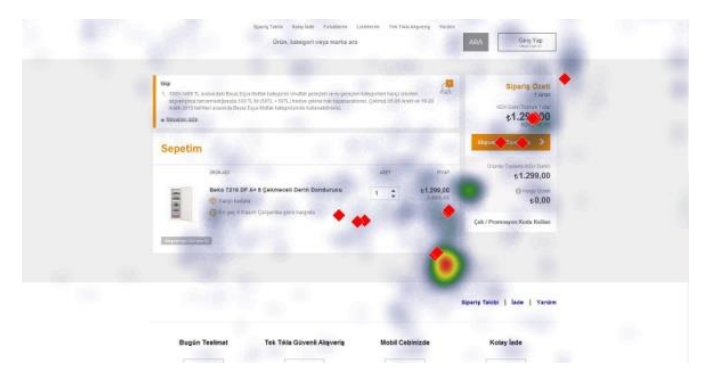

Resim 18. hepsiburada.com İnternet Sitesi Ürün ve Fiyat

Resim 18'de yer alan haritada ise deneklerin sepete ekleye tıkladıktan sonra sayfa genelinde dağılmadan ürün ve fiyat bilgisine tekrar bakılıp alışverişi tamamlaya odaklandıkları saptanmıştır.

\section{Son Test n11.com Web Sitesi Soruları}

1) n11.com sitesini incelediniz, ürün ve fiyat bilgileri sizin için yeterli geldi mi?

19 kişi ile yapılan deneylerde, n11.com sitesini inceleyen deneklerin almayı düşündükleri ürünü tıkladıklarında açılan ürün sayfasının ürün bilgisi ve fiyat bilgisi bakımından yeterli olduğu belirtmişleridir.

2)Web sitesi beklentilerinizi karşıladı mı?

Web sitesinin beklentilerini karşıladığını ancak genel yapının karışık olduğunu belirtmişleridir.

3) İnternet sitesini beğendiniz mi?

İnternet sitesi genel olarak beğenilmiştir.

4) İnternet alışverişlerinizde kullanmayı tercih eder misiniz?

n11.com sitesini internet alışverişlerinde kullandıklarını belirten 5 kişi, alışverişlerinde kullanmaya devam edeceklerini dile getirmiştir.

\section{Son Test hepsiburada.com Web Sitesi Cevapları}

1) hepsiburada.com sitesini incelediniz, ürün ve fiyat bilgileri sizin için yeterli geldi mi?

19 kişi ile yapılan deneylerde, hepsiburada.com sitesini inceleyen deneklerin satın almayı düşündükleri ürünü tıkladıklarında açılan ürün sayfasının, ürün bilgisi ve fiyat bilgisi bakımından yeterli olduğu belirtmişleridir. Ancak deneklerin bazıları diğer ürün bilgilerinin ve açıklamalarının birbirinden farklı olduğunu ve yeterli olmadıklarını da sorularda yer almamasına rağmen eklemişleridir.

2)Web sitesi beklentilerinizi karşıladı mı?

Web sitesinin beklentilerini karşıladığını belirtmişleridir. 
3) İnternet sitesini beğendiniz mi?

İnternet sitesi genel olarak beğenilmiştir.

4) İnternet alışverişlerinizde kullanmayı tercih eder misiniz?

hepsiburada.com sitesini internet alışverişlerinde kullandıklarını belirten 7 kişi alışverişlerinde kullanmaya devem edeceklerini belirtirken, 4 kişi n11.com internet sitesini kullanmayı düşündüklerini dile getirmiştir.

\section{n11.com ve hepsiburada.com Son Test Ortak Soruları}

1) İki farklı yöntem kullanarak derin dondurucu sepete eklediniz. Sizce hangi yöntem daha kullanışlıydı?

Hepsiburda.com internet sitesinin her iki deney tasarısını da çok rahat kullandıklarını ancak arama butonunun sadece belirli bir ürünün, belirli bir modelini bulurken kullanabileceklerini söylemişlerdir.

n11.com internet sitesinde iki arama butonunun daha kullanışlı olduğunu belirtmişlerdir.

2) İki farklı internet sitesinden aynı derin dondurucuyu almaya denediniz. Sizce hangi web sitesi daha başarılıydı?

hepsiburada.com internet sitesini kullanan deneklerin hepsiburada.com internet sitesini kullanmaya devam edeceklerini ve n11.com internet sitesine göre alışkın oldukları için hepsiburada.com internet sitesinin daha başarılı olduğunu belirtmişleridir. n11.com internet sitesinin de ürünü aldıktan sonra tekrar onaylanmasının çok büyük bir artı olduğunu eklemişlerdir.

n11.com internet sitesini kullanan deneklerin n11.com internet sitesinin kullanmaya devam edeceklerini belirtmişleridir. İlk test sorularında Gittigidiyor.com ve akakce.com internet sitelerini kullandıklarını belirten deneklerin de n11.com internet sitesini kullanmak istediklerini belirtmişlerdir.

\section{Sonuç}

19 denekle yapılan web kullanılabilirlik testinde deneklerden 2 farklı web sitesinden 2 farklı yöntem kullanarak aynı ürünü bulmaları, incelemeleri ve sepete eklemeleri istenmiştir.

7 kişi hepsiburada.com internet sitesinden alışveriş yaptıklarını ilk testte belirtirken 5 kişi de n11.com internet sitesinden alışveriş yaptıklarını belirtmişlerdir. Bu noktada web sitesine son derece hâkim oldukları, bakışların sayfa geneline dağılmadı̆̆ı, ürünü kolay buldukları tespit edilmiştir.

Başlangıç sayfasında deneklerin bakış haritaları doğrultusunda yapılan tespitlere göre, hepsiburada.com internet sitesi, n11.com internet sitesine göre daha net ve anlaş11ır bulunmuştur. Göz izleme literatürüne göre yazılar soldan sağa doğru okunur. (Eyice Başev, 2015, s.34). 
hepsiburada.com internet site menüsü de soldan sağa doğru aktığı için deneklerin çok daha hızlı sonuca ulaştığ 1 belirlenmiştir. Ancak n11.com internet sitesinin de deneklerce soldan sağa ve yukarıdan aşağıya incelendiğinde menünün kolaylıkla okunduğu tespit edilmiştir.

1.Deney tasarına göre hepsiburada.com internet sitesinin n11.com internet sitesine göre daha pratik ve hızlı olduğu belirlenmiştir. Ürün ve fiyat bilgisinin rahat okunduğu saptanmıştır. Sepete ekle seçeneğinde ise deneklerin bazılarının ürünü incelemeden Beko Derin Dondurucu sayfasından ürünü sepete ekledikleri belirlenirken bazılarının ürünü inceledikten sonra ürünü sepete ekledikleri belirlenmiştir.

n11.com internet sitesinde ise ürün ve fiyat bilgisinin okunuşunun daha uzun sürdüğü belirlenmiştir. Deneklerin hızlı al seçeneğine de yöneldikleri belirlenirken, sepete ekle seçeneğinin, hızlı al seçeneğinden daha çok tıklandığı belirlenmiştir.

2.Deney tasarısına göre hepsiburada.com internet sitesinin ve n11.com internet sitesinin arama butonu kullanarak ürün bulma yöntemi son derece hızlıdır. İki internet sitesi birbirinden farklı sonuç vermemektedir ancak deneklerin ortak fikri arama butonu kullanımının alacakları ürün ve modelin belli olduğunda zamanlarda kullanılması yönündedir.

Genel değerlendirmeden çıkan sonuçlara göre, deneklerin internet sayfalarının geneline çok dağılmadıkları, istedikleri ürününe kısa sürede ulaştıkları, ürün adına, modeline, fiyatına, kargo bedava yazısına yoğunlaştıkları, yazıları soldan sağa, yukarıdan aşağıya doğru okudukları tespit edilmiştir.

\section{KAYNAKLAR}

Akınc1, D., \& Çağıltay, K. (2004) E-devlet Web Sitelerini Kullanmak ya da Kullanamamak: Vatandaş Açısından Kullanılabilirlik Sorunları ve Öneriler

AL-Khalidi, F., Saatchi, R., Elphick, H. \& Burke, D. (2011). An Evaluation of Thermal Imaging Based Respiration Rate Monitoring in Children. American Journal of Engineering and Applied Sciences, 4(4), 586-597.

Becker, S.A. (2004) A Study of Web Usability for Older Adults Seeking Online Health Resources, ACM Transactions on Computer-Human Interaction, 11:4, 387-406

Bielecki M., Potega vel Zabik K., Gochna M., Mikulski J. (2017). Mass Measurement of EyeMovements Under the Dome - Proof of Concept Studies. ECEM 2017 Program and Abstracts Eds. Radach R., Deubel H., Vorstius C., Hofmann MJP121.

Bruun, A., \& Stage, J. (2015). An Empirical Study of the Effects of Three Think-Aloud Protocols on Identification of Usability Problems. In Human-Computer Interaction - INTERACT 2015: 15th IFIP TC 13 International Conference, Bamberg, Germany, September 14-18, 2015, Proceedings, Part II (pp. 159-176). Springer.

Çalışan, M., \& Türkoğlu, İ. (2011). Termal Kameralar ve Uygulamaları. Elektrik-Elektronik Bilgisayar Sempozyumu (FEEB 2011), 46-50 
Efron, N., Young, G., \& Brennan, N. A. (1989). Ocular Surface Temperature. Current Eye Research, 8(9), 901-906.

Eyice Başev, S. (2015). Tv Reklamlarının, Çocukların Seçim, Algi/Tutum, Beğeni ve Tavsiye Etme Davranışlarına Etkisi: Geleneksel ve Yeni Araştırma Yöntemlerinin Karşılaştırılması. (Yayımlanmamış doktora tezi). Bahçeşehir Üniversitesi Sosyal Bilimler Enstitüsü, İstanbul

Gescheider, G. (1997). Psychophysics: The Fundamentals

Kim, J., Thomas, P., Sankaranarayana, R., Gedeon, T., \& Yoon, H. (2015). Eye-Tracking Analysis of User Behavior and Performance in Web Search on Large and Small Screens. Journal of the Association for Information Science and Technology, 66

Mora, K., \& Odobez, J. (2014). Geometric Generative Gaze Estimation (G3E) for Remote RGBD Cameras. 2014 IEEE Conference on Computer Vision and Pattern Recognition, 17731780.

Shillcock R., Wase C. Mass measurement of Fixation Behaviors and Audience Nature in a Realistic Educational Setting. (2015). ECEM 2015 Program and Abstracts Eds. Ansorge U., Ditye T., Florack A., Leder HP66.

Siegfried, R., \& Odobez, J. (2017). Supervised Gaze Bias Correction for Gaze Coding in Interactions.

Tullis, T.S., \& Stetson, J.N. (2004). A Comparison of Questionnaires for Assessing Website Usability.

Velez, O., Okyere, P.B., Kanter, A., \& Bakken, S. (2014). A usability Study of a Mobile Health Application for Rural Ghanaian Midwives. Journal of Midwifery \& Women's Health, 59 2, 184-91 .

Yeni, S., \& Esgin, E. (2015). Usability Evaluation of Web Based Educational Multimedia by EyeTracking Technique. vol. 5, no. 4, pp. 590-603 bak

Wang, Q., Boccanfuso, L., Li, B., Ahn, A.Y., Foster, C.E., Orr, M.P., Scassellati, B., \& Shic, F. (2016). Thermographic Eye Tracking. ETRA.

Weichbroth, P., Redlarski, K., \& Garnik, I. (2016). Eye-Tracking Web Usability Research. 2016 Federated Conference on Computer Science and Information Systems (FedCSIS), 16811684. 